\title{
Factors affecting post-fire crown regeneration in cork oak (Quercus suber L.) trees
}

\author{
Filipe Xavier Catry $\cdot$ Francisco Moreira $\cdot$ Inês Duarte • \\ Vanda Acácio
}

Received: 24 January 2008 / Revised: 14 November 2008 / Accepted: 14 January 2009 / Published online: 14 February 2009 (C) Springer-Verlag 2009

\begin{abstract}
Cork oak (Quercus suber) forests are acknowledged for their biodiversity and economic (mainly cork production) values. Wildfires are one of the main threats contributing to cork oak decline in the Mediterranean Basin, and one major question that managers face after fire in cork oak stands is whether the burned trees should be coppiced or not. This decision can be based on the degree of expected crown regeneration assessed immediately after fire. In this study we carried out a post-fire assessment of the degree of crown recovery in 858 trees being exploited for cork production in southern Portugal, 1.5 years after a wildfire. Using logistic regression, we modelled good or poor crown recovery probability as a function of tree and stand variables. The main variables influencing the likelihood of good or poor crown regeneration were bark thickness, charring height, aspect and tree diameter. We also developed management models, including simpler but easier to measure variables, which had a lower predictive power but can be used to help managers to identify, immediately after fire, trees that will likely show good crown regeneration, and trees that will likely die or show poor regeneration (and thus, potential candidates for trunk coppicing).
\end{abstract}

Keywords Cork oak - Wildfires · Crown regeneration · Forest management

Communicated by C. Ammer.

F. X. Catry $(\bowtie) \cdot$ F. Moreira $\cdot$ I. Duarte $\cdot$ V. Acácio

Centro de Ecologia Aplicada "Prof. Baeta Neves", Instituto Superior de Agronomia,

Universidade Técnica de Lisboa, Tapada da Ajuda, 1349-017 Lisbon, Portugal

e-mail: fcatry@ isa.utl.pt

\section{Introduction}

Cork oak (Quercus suber L.) forests and derived agro-forestry systems play a very important ecological, economic and social role in some countries of the Mediterranean Basin (Natividade 1950; Castro et al. 1998; Mendes et al. 2004; Silva and Catry 2006; WWF 2007). This is the case of Portugal, which holds one-third of the world's cork oak area (ca 730,000 ha) and more than half of the world's cork production, representing thousands of jobs (Silva and Catry 2006). The bark of the cork oak (the cork) is a valuable raw material for industry. During tree exploitation it is periodically removed by stripping off cork planks (Pereira and Tomé 2004). After each cork stripping (harvest), the tree has the capacity of producing a new bark by growing new layers of cork every year (e.g. Natividade 1950).

Cork oak area is decreasing in many regions of the Mediterranean Basin and the species is considered endangered (Pausas 1997). There are several factors contributing to cork oak decline in the last decades, including agricultural overexploitation, overgrazing, forestation with other species, urbanisation, pests, diseases and wildfires. In Portugal wildfires are an increasing problem, which has affected 13$20 \%$ of the cork oak area since 1990 , and can be presently considered as one of the major causes of cork oak decline (Silva and Catry 2006).

Post-fire tree survival and regeneration capacity are influenced by factors related to both fire severity and individual tree characteristics (Ryan 1982; Bond and van Wilgen 1994; Whelan 1995; DeBano et al. 1998; Miller 2000; McHugh and Kolb 2003; González et al. 2007). Fire severity is function of fire intensity and duration of burn, both influenced by climatic, topographic and vegetation characteristics (e.g. Rothermel 1983; Whelan 1995; Schwilk et al. 2006). Tree resistance to fire depends largely on the 
presence of fire adaptative traits that protect its critical tissues and on carbohydrate reserves (Whelan 1995; DeBano et al. 1998). Numerous studies indicate that the time taken for cambial cells to reach a lethal temperature is a function of both bark thickness and thermal properties of the bark (e.g. Bond and van Wilgen 1994). In the case of cork oak, one of the main factors that confers fire resistance is the bark (cork), which has excellent insulating properties due to its most important chemical constituent (suberin), and its high (90\%) proportion of air and low moisture contents (Natividade 1950; Amo and Chacón 2003). In fact cork oak is the only European tree with above-ground sprouting capability when all the crown is burned (Pausas 1997), which is a big advantage in terms of a rapid post-fire recovery. However, as cork oaks are usually debarked (stripped) after they reach about 19$22 \mathrm{~cm}$ diameter, and because this procedure is commonly repeated every $9 / 12$ years, due to the economic value of the cork, often when a fire occurs bark thickness is low and it may not provide adequate protection to the tree (e.g. Moreira et al. 2007).

Although cork oak is highly fire resilient, there are other factors beside bark thickness that can affect individual resistance and response in different conditions, and the accumulation of different pre-fire or post-fire physiological stresses (like drought, soil erosion, branch pruning, fire, pests and diseases) can also contribute to the decay of vitality or may lead to the individual's death (Natividade 1950; Cabezudo et al. 1995; Amo and Chacón 2003).

Several studies showed that cork oak post-fire mortality is rather variable (Lamey 1893; Cabezudo et al. 1995; Pausas 1997; Barberies et al. 2003; Catry et al. 2006; Moreira et al.
2007), but few evaluated the vigour of crown regeneration of surviving trees and the factors related to it. Because in many cases survival is not synonymous to vitality and good economic and ecological function, it is important to be able to predict what kind of damages can be expected due to a disturbance like wildfires. This knowledge will allow taking practical measures to minimise these damages and to improve post-fire management planning. For example one major question that managers face after wildfires in cork oak stands is whether the burned trees should be coppiced or not, in order to promote regeneration from basal sprouts, as there is some evidence that early coppicing can reduce mortality and increase speed recover on much damaged trees (Barberis et al. 2003; Pintus and Ruiu 2004).

In the present paper, we question whether it is possible to identify, immediately after fire, trees that will likely show good or poor crown recover in the future. For this purpose we developed models which are intended to constitute decision-support tools helping managers to identify trees that will likely recover well, and trees that will likely die or show poor crown regeneration (and thus, potential candidates for trunk coppicing).

\section{Methods}

Study area and plot definition

The study area is located in "Serra do Caldeirão", a mountain area in the northeastern part of the Algarve district, southern Portugal (Fig. 1). The climate is Mediterranean, with average annual temperature of $16.6^{\circ} \mathrm{C}$ and average

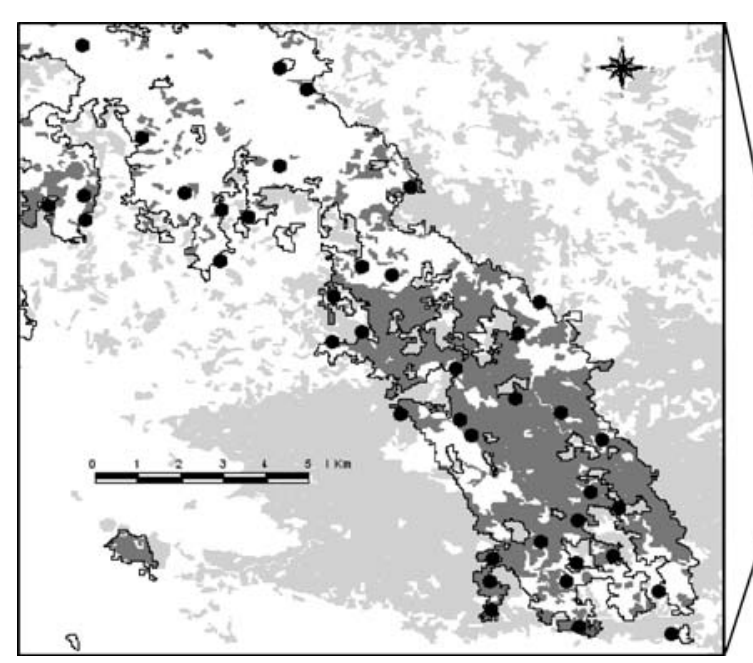

Fig. 1 On the right general distribution of cork oak in the Mediterranean Basin (based on Bozano and Turok 2002) and location of the study area, left cork oak stands in the study area (light grey) and cork

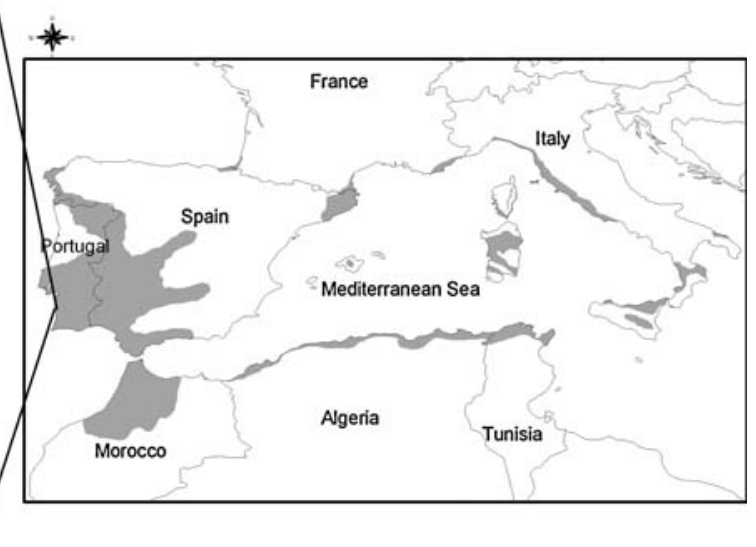

oak burned area (dark grey)—black line shows the 2004 fire perimeter and dots show the location of the 40 study plots 
annual rainfall of $900 \mathrm{~mm}$. Altitude ranges from 150 to $570 \mathrm{~m}$ and soil type consists mainly of shallow schist lithosols. The landscape is characterised by cork oak woodlands with varying tree cover, where the understory is mainly composed of Arbutus unedo, Cistus spp., Ulex spp., and Erica spp. Other vegetation types include shrublands dominated by Cistus ladanifer, and scattered stands of maritime pine (Pinus pinaster) and eucalyptus (Eucalyptus spp.), sometimes mixed with cork oak stands.

In July 2004 a large wildfire burned about 25,000 ha in this region. We used a regular $1 \times 1 \mathrm{~km}$ grid of points covering part of the burned area (ca 15,000 ha; Fig. 1) and we defined a 50 m-radius circle (sampling plot) around each point. The plots were checked in the field for accessibility, to confirm if they were burned and if they were dominated by cork oak trees. The plots were discarded if these three conditions were not simultaneously met. A total of 40 plots were selected and assessed.

\section{Plot variables}

For each 50-m circular plot, tree and shrub percent cover prior to fire were visually estimated (to the nearest 5\%) using aerial photographs (taken in 2002) and with the help of a reference scheme designed to evaluate ground vegetation cover (DGF 1999). Additionally, up to four strip transects were defined in each plot (see "Tree variables"), and the understory percent vegetation cover prior to fire was visually estimated in the field for each transect, and classified as sparse/nil (0-50\% cover), medium $(50-75 \%)$ or dense $(75-100 \%)$, based on the amount and size of burned shrub remains (and on resprouting vegetation). The modal height of this pre-fire vegetation was also estimated (to the nearest $10 \mathrm{~cm}$ ) from the height of scorched branches. For some transects these variables could not be measured as post-fire management actions (e.g. ploughing) had occurred. Topographic variables registered in each transect within each plot were the dominant aspect and the dominant slope (measured with a hypsometer). The values for the plot and within-plot (transect) variables (Table 1) were used to characterise all trees in a given plot and transect.

Tree variables

Individual tree evaluation in the plots took place between December 2005 and April 2006, so roughly 1.5 years after the fire. Trees were assessed along four 50-m strip transects departing from the plot centre at right angles. Given the very high young tree density in many plots, only trees larger than $9 \mathrm{~cm}$ diameter at breast height $(\mathrm{DBH})$ were measured. Trees along each transect were measured to obtain a sample of 30 trees per plot. In plots with higher tree density, one transect was enough to attain this sample size. In other plots, up to four transects had to be sampled. In a few plots this maximum was not achieved, thus the range was $14-30$ trees per plot and the median was 30 trees.

A total of 1,151 trees were sampled, and several variables were measured for each tree (Table 1), related to: (a) tree size (tree height, measured with a hypsometer, and $\mathrm{DBH}$, taken as the average of two perpendicular measurements); (b) fire damage indicator (minimum and maximum scorch height, both expressed as a proportion of tree height); (c) cork bark thickness (average thickness at breast height, taken from four measurements made with a bark gauge around the trunk); additionally cork age in 2004 was taken from ring counts in the bark or from the stripping year, frequently painted on the bark for management purposes; (d) cork stripping (the presence/absence of cork

Table 1 Descriptive statistics of the variables considered in this study

\begin{tabular}{|c|c|c|c|c|c|c|}
\hline Variable & Level of measurement & $n$ & Minimum & Maximum & Mean & SD \\
\hline Aspect ( 8 categories) & Transect & 858 & - & - & - & - \\
\hline Slope $(\%)$ & Transect & 858 & 12.3 & 32.4 & 21.2 & 4.02 \\
\hline Understory cover (3 categories) & Transect & 729 & Sparse & Dense & - & - \\
\hline Understory height $(\mathrm{cm})$ & Transect & 789 & 80 & 350 & 154.4 & 54.22 \\
\hline Shrub cover (proportion) & Plot & 858 & 0.05 & 0.90 & 0.40 & 0.23 \\
\hline Tree cover (proportion) & Plot & 858 & 0.20 & 0.80 & 0.33 & 0.15 \\
\hline Bark age in 2004 (years) & Tree & 858 & 0 & 13 & 4.81 & 3.03 \\
\hline Diameter at breast height $(\mathrm{cm})$ & Tree & 858 & 10.5 & 91.0 & 30.7 & 11.90 \\
\hline Maximum charring height & Tree & 858 & 0.2 & 1.00 & 0.79 & 0.21 \\
\hline Mean bark thickness $(\mathrm{cm})$ & Tree & 858 & 0 & 6.35 & 2.39 & 1.28 \\
\hline Minimum charring height & Tree & 858 & 0 & 1.00 & 0.29 & 0.34 \\
\hline Tree height (m) & Tree & 858 & 1.8 & 14.7 & 7.8 & 2.01 \\
\hline
\end{tabular}

Level of measurement relates to whether the variable was measured at the plot, transect or tree level $n$ sample size, $S D$ standard deviation 
stripping was registered for every tree, in order to separate trees in which cork exploitation had started and taken place at least once (hereafter named exploited), from trees that had never been stripped); and (e) crown regeneration status (the proportion of main branches in the crown showing signs of regeneration was visually estimated and classified into five different classes: $0,0-25,25-50,50-75,>75 \%$ ); additionally, in case of crown regeneration, the degree of sprouting along the branches was visually classified into three classes: much localised (regeneration appearing only in isolated branch sections), intermediate, and homogeneous (regeneration appearing along the whole branch length).

Large within-plot variability in tree size and cork bark thickness was common, as cork had not been extracted simultaneously from all individuals.

\section{Data analysis}

For the purposes of this paper, we restricted the analysis to trees where cork extraction had already started (858 trees) as they represent by far the more common tree type in Portuguese cork oak stands and constitute the main concern of forest managers because of their economic value. We considered that a tree had good crown regeneration if more than $75 \%$ of the main branches in the crown showed a homogeneously distributed regeneration. On the other hand we considered that a tree had poor/nil crown regeneration (hereafter named poor crown regeneration) if the sprouts appeared in $<50 \%$ of the main branches or if it was much localised (also including trees which only resprouted from basal buds or dead trees). According to this criterion trees with an intermediate regeneration state were not assigned to any of the previous groups.

Logistic regression (Hosmer and Lemeshow 1989) was used to find which variables had a significant influence on good or poor post-fire crown regeneration in exploited cork oak trees. To model good post-fire crown regeneration the trees were separated in two groups by a binary coding (coded as 1 if good regeneration was present, and as 0 otherwise), and the same procedure was made to model poor/nil post-fire crown regeneration (trees were coded as 1 if poor regeneration was present, and as 0 otherwise).

Data analysis proceeded in two steps. First, two models (one for good and other for poor regeneration) based on the original variables were built (hereafter named biological models). After a preliminary screening of recovery probabilities in different aspect orientations, due to the low number of trees located in SW slopes (20), such trees were pooled with trees in slopes oriented towards $\mathrm{S}$, creating a $\mathrm{S}+\mathrm{SW}$ category. Cork bark age was not included in this model, as bark thickness is the relevant biological variable. Understory cover and aspect were analysed as categorical variables. The significance of each variable was first tested through a univariate model, by using the likelihood-ratio $\chi^{2}$ statistic. Highly significant variables $(P<0.001)$ were retained for the multivariate logistic models. Both forward and backward stepwise selection approaches yielded the same final models. Model performance was assessed through the likelihood ratio statistic and by calculating the area under the receiver operating characteristics (ROC) curve (Pearce and Ferrier 2000; Saveland and Neueschwander 1990). Based on the results of these models, simpler models (again one for good and other for poor regeneration) were built (hereafter named management model), which intended to be more practical and easier to apply in the field. In these management models, bark age, easier to determine by managers, was used instead of bark thickness. Additionally, other variables were recoded into categories to which trees could be easily assigned in the field. Cut points to define these categories were established based on visual inspection of patterns of crown regeneration in relation to different binning classes (by verifying which cut point values would yield a biggest increase or decrease in the proportion of trees with good or poor crown regeneration). We opted to establish two binning classes for each variable in order to simplify the field evaluation procedures and the graphical representation of obtained results. In the model to predict good crown regeneration, the following variables were created: minimum charring height ${ }_{1}$ (taking the value 0 if charring height $>1 / 2$ of tree height, and 1 for the remaining), aspect ${ }_{1}$ (taking the value 0 for exposures $\mathrm{S}, \mathrm{SW}, \mathrm{E}$ and $\mathrm{N}$, and 1 for the remaining), and $\mathrm{DBH}_{1}$ (taking the value 0 if $\mathrm{DBH}>40 \mathrm{~cm}$, and 1 for the remaining). In the model to predict poor crown regeneration, variables were: minimum charring height (taking the value 0 if charring height $>1 / 3$ of tree height, and 1 for the remaining), aspect ${ }_{1}$ (taking the value 0 for exposures $\mathrm{S}$ and $\mathrm{SW}$, and 1 for the remaining), and $\mathrm{DBH}_{1}$ (taking the value 0 if $\mathrm{DBH}>40 \mathrm{~cm}$, and 1 for the remaining). Understory height was not included because it can be very difficult to estimate in severe fires.

Performance of both biological and management models was compared using the ROC curve and classification tables. Unless otherwise specified, values are expressed as mean \pm standard error. Correlation between explanatory variables (Spearman correlation coefficient) was usually low. The highest correlation was observed for bark thickness and bark age $(r=0.78, P<0.001)$, but they were not used simultaneously in the same model. Other relatively high values $(>0.5)$ occurred for $\mathrm{DBH}$ and tree height $(r=0.61, P<0.001)$ and for proportional minimum and maximum scorch height $(r=0.55, P<0.001)$; due to these correlations we opted to use only DBH and minimum scorch height in the logistic models, because they showed a stronger influence on the crown regeneration. All analyses were carried out using the SPSS software (SPSS 2004). 
Table 2 Results of univariate logistic regression to assess the effect of each variable on poor and good crown regeneration after fire occurrence

\begin{tabular}{|c|c|c|c|c|c|}
\hline \multirow[t]{2}{*}{ Variable } & \multicolumn{2}{|c|}{ Poor crown regeneration } & \multicolumn{2}{|c|}{ Good crown regeneration } & \multirow[t]{2}{*}{$d f$} \\
\hline & Coefficient & $\chi^{2}$ & Coefficient & $\chi^{2}$ & \\
\hline Mean bark thickness & $-\mathbf{0 . 8 0 7}$ & 147.77 & 0.327 & 34.52 & 1 \\
\hline Minimum charring height & 1.749 & 66.24 & -2.433 & 93.08 & 1 \\
\hline Aspect & Cat & 50.54 & Cat & 49.51 & 5 \\
\hline Diameter at breast height & 0.021 & 11.66 & -0.013 & 14.31 & 1 \\
\hline Understory height & 0.005 & 11.28 & -0.008 & 25.96 & 1 \\
\hline Shrub cover & 0.715 & 5.33 & -0.868 & 8.23 & 1 \\
\hline Slope & 0.040 & 4.82 & 0.013 & $0.54(\mathrm{NS})$ & 1 \\
\hline Understory cover & Cat & 0.35 (NS) & Cat & 4.40 (NS) & 3 \\
\hline Tree cover & 0.200 & 0.17 (NS) & -0.728 & $2.41(\mathrm{NS})$ & 1 \\
\hline
\end{tabular}

For each variable, the coefficient and the value of the $\chi^{2}$-test (equivalent to the change in -2 log Likelihood if the variable was removed from the model) are shown. Variables are ordered by decreasing importance in relation to poor regeneration. Highly significant variables $(P<0.001)$ are signalled in bold

NS indicate non-significant values, Cat categorical variables

\section{Results}

Tree and plot characteristics

A summary of the descriptive statistics for the studied variables is shown in Table 1 . The average cork oak tree was $7.8 \mathrm{~m}$ tall and measured $31 \mathrm{~cm}$ in DBH. Average bark thickness was $2.4 \mathrm{~cm}$ and mean cork age at the moment of the fire was about 5 years. Most trees were located in aspects oriented to NE (22\% of the trees), E (20\%) and N (18\%), whereas the less common orientation was SW $(2.3 \%)$, and no trees were located in SE aspects. Mean understory height prior to fire was $154 \mathrm{~cm}$, and the most common understory cover was medium, followed by sparse and dense vegetation. Average maximum charring height in cork oaks was $80 \%$ and minimum was $30 \%$.

\section{Variables affecting crown regeneration}

One-and-a-half years after fire occurrence, $31 \%$ of all trees presented a nil or poor crown regeneration (low probability of maintaining an economic interest in the near future), and only $37 \%$ presented good crown regeneration, while the remaining $32 \%$ presented an intermediate state. The trees which were considered with poor crown regeneration included dead trees (18\% of the total), trees which only showed regeneration from basal buds $(6 \%)$, and trees where crown regeneration appeared in less than $50 \%$ of the branches or it was only localised (7\%).

The results of univariate logistic regressions are summarised in Table 2. Among the variables significantly affecting poor crown regeneration, the more important ones were the bark thickness (the lower the mean bark thickness, the higher the probability of poor crown regeneration), charring height (the higher the minimum charring height, the higher the probability of poor crown regeneration) and aspect (worse regeneration in S, SW, E and $\mathrm{N}$ slopes). Trees with higher $\mathrm{DBH}$, or located in plots with higher understory height, higher shrub cover or higher slopes, also showed higher probability of having poor crown regeneration.

Among the variables affecting good crown regeneration, the most important ones were charring height (the higher the minimum charring height, the lower the probability of good crown regeneration) and aspect (better regeneration in $\mathrm{W}$, NW, and NE slopes). In addition, two tree variables (bark thickness and $\mathrm{DBH}$ ) influenced the crown regeneration, the former positively and the latter negatively, and two plot variables (understory height and shrub cover) were negatively correlated to good crown regeneration capability.

Probability of poor and good crown regeneration:

biological and management models

In Table 3 we present the best multivariate biological models to predict the probability of poor and good crown regeneration in exploited cork oaks. Bark thickness was the most important variable influencing the probability of poor crown regeneration, followed by aspect, DBH and proportional minimum charring height. In the model developed to predict the probability of good crown regeneration the most important variable was the minimum charring height, followed by aspect, bark thickness, understory height and DBH.

In the management models (Table 4), besides using bark age instead of bark thickness, three new binary variables were included (aspect ${ }_{1}$, minimum charring height ${ }_{1}$ and $\mathrm{DBH}_{1}$; see "Methods"). In both the models, minimum charring height was the most important variable. 
Table 3 Multivariate logistic biological models to predict poor and good post-fire crown regeneration in exploited cork oaks

\begin{tabular}{|c|c|c|c|c|c|}
\hline \multirow[t]{2}{*}{ Variable } & \multicolumn{2}{|c|}{ Poor crown regeneration } & \multicolumn{2}{|c|}{ Good crown regeneration } & \multirow[t]{2}{*}{$d f$} \\
\hline & Coefficient & $\chi^{2}$ & Coefficient & $\chi^{2}$ & \\
\hline Mean bark thickness & -0.901 & 140.47 & 0.439 & 39.51 & 1 \\
\hline Aspect & Cat & 30.51 & Cat & 49.56 & 5 \\
\hline Diameter at breast height & 0.042 & 29.21 & -0.021 & 7.66 & 1 \\
\hline Minimum charring height & 1.445 & 27.99 & -2.320 & 55.10 & 1 \\
\hline Understory height & - & - & -0.007 & 16.20 & 1 \\
\hline Constant & -1.682 & & 1.491 & & \\
\hline
\end{tabular}

For each variable, the coefficient and the value of the $\chi^{2}$-test (equivalent to the change in -2 log Likelihood if the variable was removed from the model) are shown. Variables are ordered by decreasing importance in relation to poor regeneration. (a) Poor crown regeneration: full model $\chi^{2}=248.6(d f=8 ; P<0.001)$; area under ROC curve $=0.81 \pm 0.02 ; P<0.001 ;($ b $)$ good crown regeneration: full model $\chi^{2}=184.3(d f=9$; $P<0.001)$; area under ROC curve $=0.78 \pm 0.02 ; P<0.001$

Table 4 Multivariate logistic management models, to predict poor and good post-fire crown regeneration in exploited cork oaks

\begin{tabular}{|c|c|c|c|c|c|}
\hline \multirow[t]{2}{*}{ Variable } & \multicolumn{2}{|c|}{ Poor crown regeneration } & \multicolumn{2}{|c|}{ Good crown regeneration } & \multirow[t]{2}{*}{$d f$} \\
\hline & Coefficient & $\chi^{2}$ & Coefficient & $\chi^{2}$ & \\
\hline Minimum charring height $_{1}$ & 1.360 & 63.30 & -2.388 & 96.49 & 1 \\
\hline Cork age & -0.189 & 46.59 & 0.083 & 9.88 & 1 \\
\hline Diameter at breast height $_{1}$ & 0.820 & 15.27 & -0.691 & 11.30 & 1 \\
\hline Aspect $_{1}$ & -0.653 & 9.07 & 0.847 & 30.76 & 1 \\
\hline Constant & -0.040 & & -0.921 & & \\
\hline
\end{tabular}

For each variable, the coefficient and the value of the $\chi^{2}$-test (equivalent to the change in $-2 \log$ Likelihood if the variable was removed from the model) are shown. Variables are ordered by decreasing importance in relation to poor regeneration. (a) Poor crown regeneration: full model $\chi^{2}=155.9(d f=4 ; P<0.001)$; area under ROC curve $=0.73 \pm 0.02 ; P<0.001 ;$ (b) good crown regeneration: full model $\chi^{2}=155.9(d f=4$; $P<0.001$ ); area under ROC curve $=0.73 \pm 0.02 ; P<0.001$. See also Figs. 2 and 3. Note that for minimum charring height, variable coding is different in both models

These management models were not as good as the biological models (area under ROC curves for the management and biological models were, respectively, 0.73 versus 0.81 in the model to predict poor crown regeneration, and 0.73 versus 0.78 in the model to predict good crown regeneration), but they have the advantage of being much easier to use by managers. The global accuracy assessed by classification tables (using a 0.5 cut-off point) showed a slight difference in the model to predict poor crown regeneration (77.4\% in the management model against $77.8 \%$ in the biological), but a higher difference in the model to predict good crown regeneration (67.0 against $72.8 \%$ ).

The outputs of these management models are graphically shown in Figs. 2 and 3.

\section{Discussion}

\section{Basic assumptions}

The built models were based on the assumption that trees that showed poor or good regeneration 1.5 years after fire, will likely maintain the same status in the future. It is known that mortality can be immediate or delayed for some time after fire occurrence, and that it can vary with the species, pre-fire vigour of the tree and fire severity. Because of their weakened physiological condition, fire-injured trees can also be subsequently attacked by insects or infected by diseases, increasing mortality. For example in southern Spain Cabezudo et al. (1995) observed 20\% mortality immediately after wildfire in a cork oak stand (with 6 years' old cork), but 4 months later mortality increased to $54 \%$. However, based on observations in other regions (e.g. Catry et al. 2006), we believe that trees showing good crown regeneration 1.5 years after fire will have low probability of dying or becoming very weak in the future, at least as a direct consequence of fire.

On the other hand, we do not know if some trees with present poor crown regeneration will in fact recover and are just taking longer. Only longer term monitoring can provide answers to these questions. However, in our study area, among the trees classified as having poor crown regeneration, $77 \%$ did not have any sign of new crown sprouting 1.5 years after fire occurrence, and it is not likely 


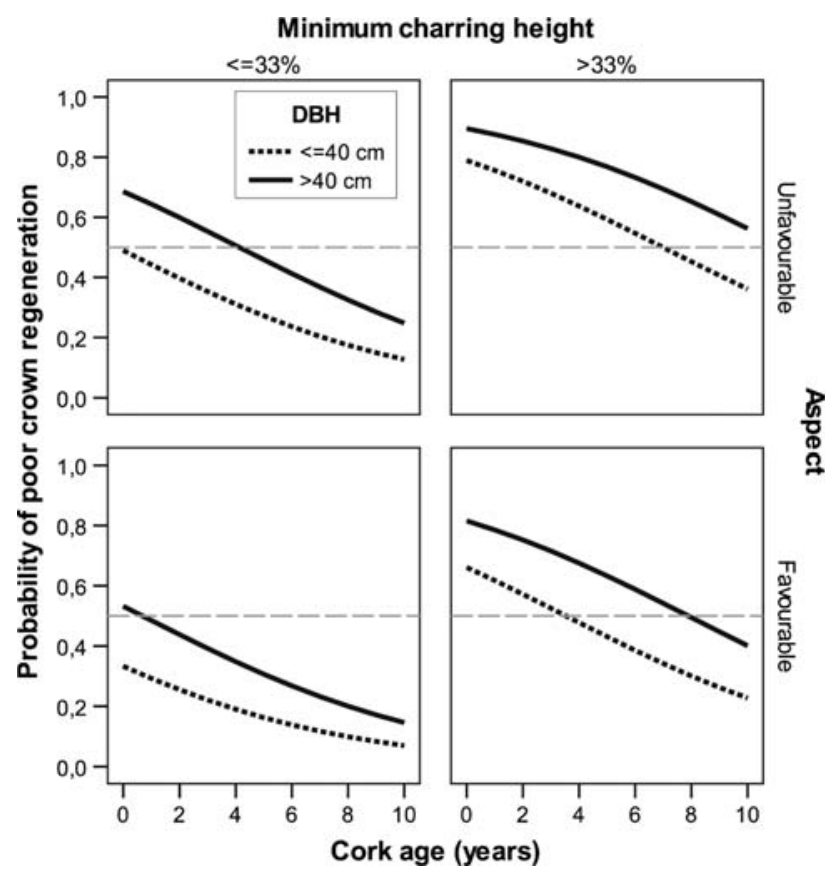

Fig. 2 Logistic model prediction of poor crown regeneration in cork oak, 1.5 years after a wildfire. Different combinations of minimum charring height (larger or smaller than one-third of tree height), aspect (favourable vs. unfavourable), cork age when the fire occurred (in years), and DBH (larger or smaller than $40 \mathrm{~cm}$ ) are shown. The 50\% probability line is also shown for each graph

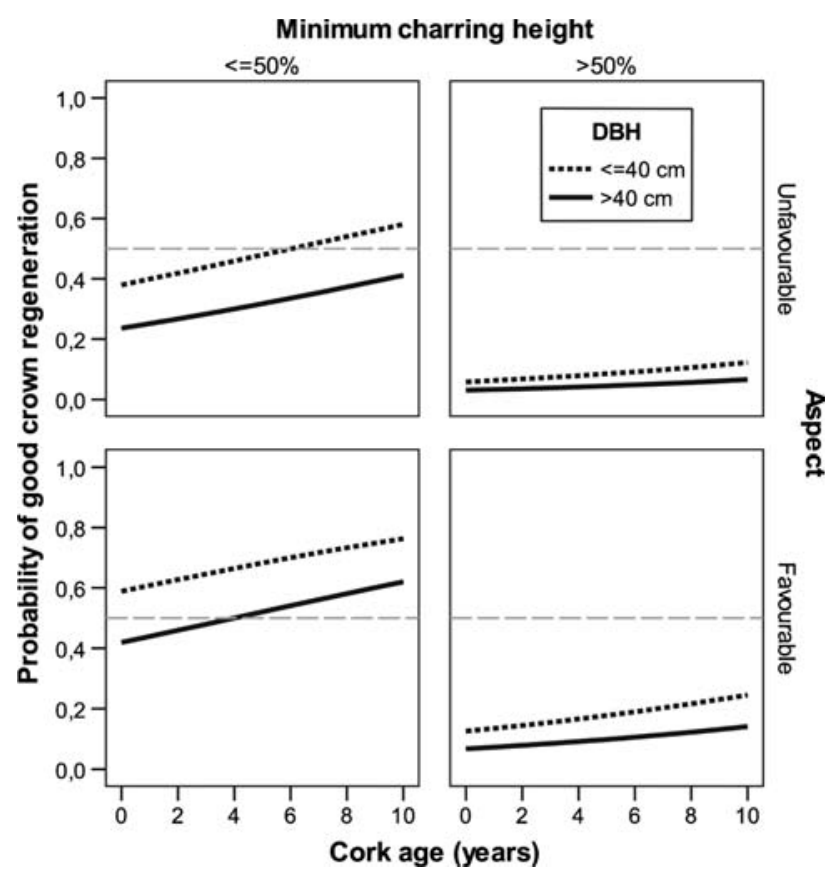

Fig. 3 Logistic model prediction of good crown regeneration in cork oak, 1.5 years after a wildfire. Different combinations of minimum charring height (larger or smaller than half of tree height), aspect (favourable vs. unfavourable), cork age when the fire occurred (in years), and DBH (larger or smaller than $40 \mathrm{~cm}$ ) are shown. The $50 \%$ probability line is also shown for each graph that this situation will change. The remaining trees (23\%) had no signs of regeneration in more than a half of the crown or it was much localised, and in these cases we considered that the probability of good recovery in the future, allowing a normal economic exploitation, is very low.

Finally, concerning the method for assessing the crown regeneration status (see Methods) we recognise that it has some inherent subjectivity, like it happens in many other visual estimation methods. However, visual estimations are often used in research studies (e.g. Ryan and Reinhardt 1988; Thies et al. 2006) when other methods are not possible or are difficult to apply. In this study the visual estimations were based on a reference scheme with broad categories and were always done by the same person, thus we assumed that the method was sufficiently robust to minimise the subjectivity in the evaluation.

\section{Biological correlates of crown regeneration}

The present study showed that bark thickness is the most important variable determining the probability that a cork oak will have a poor (or nil) crown regeneration. In a previous study (Moreira et al. 2007) we showed that in exploited cork oaks, bark thickness was the most important variable determining post-fire survival, and other authors also showed the crucial importance of this variable in conferring a higher resistance to fire (e.g. Lamey 1893; Pausas 1997; Barberis et al. 2003). However, the existence of a thick bark was not enough to guarantee good crown regeneration (bark thickness ranked third in importance in the biological model).

Minimum charring height was the most important variable affecting the probability of good crown regeneration, but showed lower influence on poor crown regeneration (ranked second in the univariate analysis and fourth in the multivariate analysis). Minimum charring height was a stronger predictor of crown regeneration than maximum height, which suggests that the former can be a better indicator of fire severity.

Aspect was the second most important variable influencing good and poor crown regeneration in the multivariate models. We found evidence that south to southwest quadrants were associated with higher probability of poor crown regeneration, probably because they have a more xerophitic character that may have caused higher physiological stress and thus higher vulnerability to fire. Simultaneously, we verified that good regeneration capability was higher on the west, northeast and northwest slopes, although it decreased on north-oriented slopes. We did not find an obvious explanation for the lower crown regeneration observed in $\mathrm{N}$ plots, but this could be due to a lower median cork age (4 years in $\mathrm{N}$ plots vs. 5 years in $\mathrm{W}+\mathrm{NW}+\mathrm{NE}$ plots), or because of some additional stress not measured and more 
prevalent in those trees (e.g., trees having been pruned or having more stripping damages).

Tree diameter (DBH) also influenced crown regeneration, being selected in both multivariate models. Trees with larger trunks usually correspond to older trees, which were more often submitted to stripping, as well as likely poor management practices (e.g., stripping damages or excessive crown pruning) and may be more susceptible to fire or other stresses (Natividade 1950; Santos and Sousa 1997; Barberis et al. 2003; Costa et al. 2004). The lower fire-resistance of older cork oaks, has also been showed by Barberis et al. (2003) in a study carried out in Italy, where authors observed significantly higher mortality in trees submitted to several bark strippings $(40 \%)$, than in trees debarked only once $(17 \%)$.

Trees located in plots with higher understory had lower probability of good crown regeneration, which is predictable as fire severity usually increase with increasing understory height (Rothermel 1983). However, this variable was not selected in the multivariate model to predict poor crown regeneration. Scorch height seemed to be a better indicator of fire severity than understory height.

As shown, there are several factors that can affect survival and regeneration capacity of cork oak trees, but bark thickness and charring height are among the most important. In our study only 110 trees (13\%) had signs of having been completely scorched to the top (minimum charring height, 100\%), and among those trees there was a much higher proportion showing poor crown regeneration when compared to all trees ( 51 vs. $31 \%$ ), and only $5 \%$ showed good crown regeneration. It is also to notice than only 140 trees $(16 \%)$ had bark thickness lower than $1 \mathrm{~cm}$ when the fire occurred, and among those $68 \%$ presented poor crown regeneration ( $41 \%$ mortality) and only $11 \%$ showed good crown regeneration. In the monitored trees it was evident that the accumulation of the two negative effects of having been completely scorched and having a thin bark highly affected the capacity of crown recover. Among trees with less than $1 \mathrm{~cm}$ bark thickness and scorched to the top (37 trees), $97 \%$ presented poor crown regeneration (76\% mortality) and none showed good crown regeneration.

How to quickly evaluate tree response: management models

The management models, simpler than the biological models, had a lower explanatory power and fit to the data, as it could be expected due to the simplification of the explanatory variables. Anyway, their accuracy is adequate in order to be usefully applied in the field. The main differences were the higher importance of minimum charring height and the lower importance of cork age in the former models. For cork age, this is probably because it is not such a good predictor of bark thickness as this measure itself. Because of the constraints associated with plots located in North exposures, this exposure should probably be excluded from the unfavourable exposure category and it should be assumed that in normal circumstances, crown regeneration is likely similarly good in $\mathrm{W}, \mathrm{NW}, \mathrm{N}$ or NE exposures.

The probabilities obtained from the application of the two management models (to predict poor and good crown regeneration) to a given tree are negatively correlated as expected, meaning a decreasing probability of poor crown regeneration as the probability of good crown regeneration increased $(r=-0.874 ; P<0.001)$. In just a few cases a tree had simultaneously high probabilities of having both poor and good crown regeneration. If a 0.5 cut-off point was used to assign predicted probability to a given crow regeneration status, only $1.4 \%$ of all trees would show conflicting results (which would decrease for increasing cut-off points).

The obtained management models provide an easier way of getting an estimate of crown regeneration probability from only four variables that can be easily measured in the field immediately after a wildfire.

Implications for management

There are different kinds of potential losses associated with burned cork oak stands. One of the most important is the end or the reduction of cork production in exploited trees, because the scorched cork is much less valuable, and because trees can die or become very weak, not being able to recover in order to assure a normal cork production in the future.

The presented models of post-fire crown regeneration probability in cork oak stands in southern Portugal (both biological and management), can be used as decision-support tools that will help managers from this region to identify, immediately after fire, trees that will likely show poor or good crown regeneration.

One of the main questions that managers often face after wildfires in cork oak stands is whether the burned trees should be coppiced or not, and when they should be coppiced. Several authors mentioned that trunk coppicing is a good option when trees have serious stem damages that compromise future cork production, and when the crown regeneration is predicted nil or very weak (Lamey 1893; Pampiro et al. 1992; Amo and Chacón 2003; Barberies et al. 2003; DGRF 2006). In that case, coppicing burned trees may be a better strategy than waiting for potential crown regeneration, as there is some evidence that coppiced trees can have higher survival than non-coppiced trees or than trees coppiced later, and that sucker growth (both in height and diameter) can also be higher (Barberis et al. 2003; Pintus and Ruiu 2004). 
However, the decision of cutting or leaving the trees without intervention is not straightforward because cutting a burned tree implies waiting 15-25 years before the suckers are big enough to be debarked again (Amo and Chacón 2003; Barberies et al. 2003). Additionally, if many trees are in bad conditions it can be a better option, for ecological reasons, to maintain more trees to improve protection against soil erosion and wildlife habitat. Some authors suggest waiting until the spring after the fire, or even to the following autumn, to evaluate the status of each tree (Amo and Chacón 2003; DGRF 2006), although there is evidence of a higher rate of recovery when trunk coppicing is carried out before the next growing season (Pintus and Ruiu 2004; DGRF 2006). In this context, knowing immediately after fire if an exploited burned tree will show good or poor crown regeneration may help management decisions.

Because several factors are involved in cork oak dynamics, the evaluation of the damages and the decisions about the future actions to take are not simple. For example a Portuguese Forest Services publication (DGRF 2006) tried to simplify the procedures to evaluate the damages, considering/recommending that a cork oak stripped less than 4 years before the fire should be coppiced. However, in this study we found that in fact $31 \%$ of these trees showed good crown regeneration, and only $45 \%$ showed poor crown regeneration, so we recommend being quite more prudent in identifying the trees to be coppiced.

Acknowledgments Thanks are due to Raimundo Duarte, Rebeca Alvarez, Ana Oliveira and Rui Morgado, for lab and field work, and to Francisco Rego and Miguel Bugalho for their comments. We also acknowledge the comments made by two anonymous reviewers which contributed to improve the paper. This research was carried out within the scope of projects INTERREG III-B RECOFORME, POCI/AGR/ 58896/2004, POCI/AGR/61407/2004 and FFP_Recuperação de áreas ardidas.

\section{References}

Amo E, Chacón C (2003) Recomendaciones selvícolas para alcornocales afectados por el fuego. Cuadernos Forestales, IPROCOR, Mérida

Barberis A, Dettori S, Filigheddu MR (2003) Management problems in Mediterranean cork oak forests: post-fire recovery. J Arid Environ 54:565-569. doi:10.1006/jare.2002.1079

Bond WJ, van Wilgen BW (1994) Fire and plants. Chapman \& Hall, London

Bozano M, Turok J (eds) (2002) Mediterranean Oaks Network. In: Report of the second meeting, 2-4 May 2002, Gozo, Malta. International Plant Genetic Resources Institute, Rome, Italy

Cabezudo B, Latorre A, Nieto J (1995) After fire regeneration in a Quercus suber forest in the South of Spain (Istan, Malaga). Acta Bot Malacitana 20:143-151

Castro et al (1998) Los Bosques Ibéricos. Una interpretación geobotánica. In: Tenório MC, Juaristi CM, Ollero HS (eds). Editorial Planeta, Spain

Catry FX, Rego FC, Bugalho MN, Lopes T, Silva JS, Moreira F (2006) Effects of fire on tree survival and regeneration in a Mediterranean ecosystem. In: Viegas DX (ed) Proceedings of 5th international conference on forest fire research. CD Rom. ADAI, Figueira da Foz, 5 pp

Costa A, Pereira H, Oliveira A (2004) The effect of cork-stripping damage on diameter growth of Quercus suber L. Forestry 77:1-8. doi:10.1093/forestry/77.1.1

DeBano LF, Neary DG, Ffolliott PF (1998) Fire's effects on ecosystems. Wiley, New York

DGF (1999) Manual de instruções para o trabalho de campo do Inventário Florestal Nacional. Direcção-Geral das Florestas, Lisboa

DGRF (2006) Boas práticas de gestão em sobreiro e azinheira. Direcção-Geral dos Recursos Florestais, Lisboa

González JR, Trasobares A, Palahí M, Puklala T (2007) Predicting stand damage and tree survival in burned forests in Catalonia (North-East Spain). Ann Sci 64:733-742. doi:10.1051/forest: 2007053

Hosmer DW, Lemeshow S (1989) Applied logistic regression. Wiley, New York

Lamey A (1893) Le chêne-liège, sa culture et son exploitation. BergerLevrault et Cie éditeurs, Nancy, Paris

McHugh CW, Kolb TE (2003) Ponderosa pine mortality following fire in northern Arizona. Int J Wildland Fire 12:7-22. doi:10.1071/ WF02054

Mendes A, Carvalho M, Dias R, Tavares M, Feliciano D (2004) The Portuguese forests-evaluating financing of forestry in Europe. Country level report delivered to the EFFE Project. Portuguese Catholic University, Porto Regional Centre, Faculty of Economics and Management, Porto

Miller M (2000) Fire Autecology. In: Brown JK, Smith JK (eds) Wildland fire in ecosystems: effects of fire on flora. Gen. tech. rep. RMRS-GTR-42, vol. 2. Ogden, UT, US Department of Agriculture, Forest Service, Rocky Mountain Research Station, pp 9-34

Moreira F, Duarte I, Catry F, Acácio V (2007) Factors affecting postfire cork oak survival in southern Portugal. For Ecol Manage 253:30-37

Natividade JV (1950) Subericultura. D.G.S.F.A, Lisboa

Pampiro F, Pintus A, Ruiu PA (1992) Interventi di recupero di una giovane sughereta percorsa da incêndio. In: Instituto de Promoción del Corcho (ed) Simpósio Mediterrâneo sobre Regeneración del Monte Alcornocal, Mérida, pp 174-177

Pausas J (1997) Resprouting of Quercus suber in NE Spain after fire. J Veg Sci 8:703-706. doi:10.2307/3237375

Pearce J, Ferrier S (2000) Evaluating the predictive performance of habitat models developed using logistic regression. Ecol Modell 133:225-245. doi:10.1016/S0304-3800(00)00322-7

Pereira H, Tomé M (2004) Cork oak. In: Burley J, Evans J, Youngquist JA (eds) Encyclopedia of forest sciences. Elsevier, Oxford, pp 613-620

Pintus A, Ruiu P (2004) La réhabilitation des suberaies incendiées. Colloques Internationaux Vivexpo 2004: Le chêne-liège face au feu

Rothermel R (1983) How to predict the spread and intensity of forest and range fires. General technical report INT-143. Forest Service, United States Department of Agriculture

Ryan KC (1982) Evaluating potential tree mortality from prescribed burning. In: Baumgartner DM (ed) Site preparation and fuels management on steppe terrain. Washington State University Cooperative Extension, Pullman, pp 167-179

Ryan KC, Reinhardt ED (1988) Predicting postfire mortality of seven western conifers. Can J Res 18:1291-1297. doi:10.1139/x88-199

Santos MNS, Sousa EMR (1997) Bases para a recuperação do montado de sobro e futuras linhas de actuação. In: Pereira $\mathrm{H}(\mathrm{ed})$ European Conference on Cork Oak and Cork, Lisbon, pp 294-301

Saveland JM, Neueschwander LF (1990) A signal detection framework to evaluate models of tree mortality following fire damage. For Sci 36:66-76 
Schwilk DW, Knapp EE, Ferrenberg SM, Keeley JE, Caprio AC (2006) Tree mortality from fire and bark beetles following early and late season prescribed fires in a Sierra Nevada mixed-conifer forest. For Ecol Manage 232:36-45

Silva JS, Catry F (2006) Forest fires in cork oak (Quercus suber) stands in Portugal. Int $\mathrm{J}$ Environ Stud 63:235-257. doi:10.1080/ 00207230600720829

SPSS (2004) SPSS for Windows. SPSS Inc, Chicago
Thies WG, Westlind DJ, Loewen M, Brenner G (2006) Predicting delayed mortality of fire-damaged ponderosa pine following prescribed fires in eastern Oregon, USA. Int J Wildland Fire 15:19 29. doi:10.1071/WF05025

Whelan RJ (1995) The ecology of fire. Cambridge University Press, New York

WWF (2007) Beyond cork-a wealth of resources for people and nature. World Wide Fund for Nature, Madrid 